\title{
电力系统的伟大成就及发展趋势
}

梅生伟 1,2

1. 清华大学电机工程与应用电子技术系, 北京 100084 ;

2. 电力系统及发电设备控制和仿真国家重点实验室, 北京 100084

E-mail: meishengwei@mail.tsinghua.edu.cn

2019-10-17 收稿, 2019-11-13 修回, 2019-11-14 接受, 2019-11-15 网络版发表

摘要电能是一种高品质的二次能源, 是能量及信息转换、传输的重要载体. 电力系统被列为 20 世纪最伟大的 20 项工程技术成就之首. 以“强电”为载体的电力系统构成了现代社会能量传输的大动脉, 以“弱电”为载体的通信网络 构成了现代社会的神经系统, 它们渗透到人类生产、生活和社会活动的各个层面, 推动现代文明飞跃发展. 本文回 顾了电力系统 100 多年来的光辉发展历程, 分析了电力系统对材料、物理、化学、自动化、信息、医学等现代科 学技术的影响，描述了电力系统对以“强电”的规模化应用为标志的第二次工业革命、以“弱电”的广泛应用为标志 的第三次工业革命，以及以能源革命为核心的第四次工业革命的推动作用，展示了人类社会实现由蒸汽时代到电 气时代、信息时代、绿色智能化时代的跨越式发展过程。进一步从人们的基本生活方式、国际政治经济格局等不 同层面揭示了电力系统对人类社会的重要影响，并论述了电力系统对未来能源革命的战略意义及其发展趋势，以 期对电力系统的伟大成就及演变规律形成更好的认识.

关键词电力系统, 能源动脉, 现代文明, 伟大成就, 发展趋势

电力系统包含电能生产、传输、分配和应用四大 环节, 是人类开发、利用自然能源最为重要的形式, 对 现代文明发展起到决定性作用．在美国评选出的20项 20 世纪最伟大的工程技术成就中，电力系统名列首 位 ${ }^{[1]}$. 在我国, 电力工业被称为经济发展的“先行官”, 在社会主义现代化建设过程中发挥了极其重要的作用.

以“强电”为载体的电力系统是现代社会能量传输 的大动脉. 从“源”端看, 电力系统能方便地将水能、风 能、太阳能、潮汐能等多种形式的能源转化为电能, 实现自然能源的规模化开发利用 ${ }^{[2,3]}$. 从“网”端看, 电力 系统可将相距数千千米的电源和负荷联结在一起, 摆 脱地域对能源生产和利用的限制. 从“荷”端看, 能源可 以被送到各行各业和千家万户，支撑现代社会正常 运转.
以电能为驱动的电气化设备是现代社会高速前进 的车轮. 随着大量电传动、电转热、电转光等设备的 成功研究与推广应用，工业、商业、农业等产业及居 民生活逐渐建立在形形色色的电气化设备之上 ${ }^{[4]}$. 以 电能应用为核心、以电力系统为平台、以提高生产力 水平和生活质量为目标的电气化社会已经形成，电气 化水平也在很大程度上成了衡量现代社会文明程度的 重要依据.

以“弱电”为载体的通信网络是现代社会的神经系 统. 随着电能由“强电”往“弱电”方向延伸，由传感设 备、通信设备、通信网络、计算机软硬件等组成的信 息系统已经渗透到现代社会的方方面面，使现代社会 完全处于可观测、可感知的状态，并对人们的行为方 式和价值观念产生深刻影响 ${ }^{[5,6]}$. 信息甚至成了比物质 
更为重要的资源，在人类的生产、生活和社会活动中 产生高附加值 ${ }^{[7]}$.

本文拟回顾100多年来电力系统的光辉发展历程, 揭示电力系统对现代文明的巨大推动作用, 并从传承 和创新发展的视角, 对未来电力系统的形态和发展趋 势进行探讨，以期更完整地认识电力系统的伟大成就 及发展趋势

\section{1 电力系统的发展历程}

从能源形式看, 电能处于能量品位最高端, 但它最 初游离在人类认识之外, 完全是一个人造奇迹. 与机械 能、热能、光能等一次能源不同，电能作为一种二次 能源难以被直接观测，这就注定了人类对电能的认识 是一个漫长而曲折的过程 ${ }^{[8]}$. 以下将以人类对电能的 认识和利用为主线, 对电源的起源及电力系统的发展 过程进行简要回顾.

\section{1 电能的起源}

早在远古时代，人类就从雷电中观察到了大自然 的放电现象, 但由于雷电产生过程短、破坏力强, 这在 当时完全超出了人们的认识范畴，人们只能从神学的 角度进行解释. 公元前 6 世纪, 古希腊哲学家记载了摩 擦的琥珀能吸引小物体的现象. 在我国古代, 人们也在 探寻铁矿的过程中发现了磁的现象，并于战国时期发 明了指南针的前身——司南. 磁现象虽然可以观测, 但 人们并不了解其中的作用机理，对电能的认识更无从 谈起.

人类对电磁规律的认识与利用, 经历了从静电到 电磁感应再到电能生产的漫长过程 ${ }^{[9-11]}$. 1600年, 英国 科学家吉伯发表了《论磁体》，这是人类第一篇有关 磁学的著作, 标志着磁学正式诞生. 1820年, 奥斯特发 现了电流的磁效应，发表了一篇题为《关于磁针上的 电冲突作用的实验》的论文，在科学界引起了巨大反 响. 1831年，法拉第通过实验提出了电磁感应定律，揭 示了电磁与电能的定量关系, 为电能生产奠定了理论 基础. 此后, 法拉第进一步发明了人类历史上第一台发 电机，在工程上实现了磁到电的重大飞跃. 1864年, 麦 克斯韦发现了电磁场的空间分布规律及其随时间的变 化规律, 并通过麦克斯韦方程进行精确描述, 使人们对 电磁现象有了更为全面、深刻的认识. 麦克斯韦又进 一步预言了电磁波的存在, 分析了其传播机理, 至此电 工学科的理论体系基本成形. 此后, 经过大量科学先驱
的探索，电工理论与技术不断得到完善，人类自此迈进 了大规模电能利用时代.

\section{2 电力系统的起源与发展}

电力系统的起源与发展，是发电机、电动机、变 压器等电力设备及输配电技术发展的必然结果. 1882 年9月，爱迪生在纽约建立了第一个完整的直流电力系 统. 该系统包含总容量约为 $670 \mathrm{~kW}$ 的 6 台直流发电机, 可为纽约市区内半径约 $1.5 \mathrm{~km}$ 的区域提供照明用电. 但由于其规模、供电能力和高昂建设费用的限制，在 当时并未引起足够重视．随着交流发电机、变压器、 感应电动机等交流电力设备的成功研究，基于三相交 流输电技术建立的电力系统的输电容量与输电距离迅 速扩大．1895年，美国尼亚加拉水电站采用 $11 \mathrm{kV}$ 交流 输电线路, 将 $1.0 \times 10^{5} \mathrm{~kW}$ 的电能输送至 $40 \mathrm{~km}$ 开外的巴 法罗电站, 首次实现了高电压远距离输电. 此后, 电力 系统的电压等级不断提高, 输电距离和装机容量不断 增大 ${ }^{[12 \sim 15]}$. 人们也认识到“更高、更远、更大”的电力 系统有利于电能的大规模开发利用，在供电能力、供 电可靠性、电能质量、经济性等方面具有明显优势. 于是, 各种小型的区域电网逐渐被联结起来, 人类社会 进人了大电网时代.

经过一个多世纪的发展，电力系统已经发展成为 世界上最大的人造系统，其规模庞大，结构复杂，技 术、资金和人员密集，堪称人类科学史上最伟大的工 程成就. 目前, 世界上已经形成了多个规模巨大的电力 系统. 若干电力系统甚至突破了国界的限制, 成为全球 能源一体化的先行者，典型者如覆盖美国、加拿大和 墨西哥北部的北美电力系统，覆盖欧洲大陆24个国家 和地区的欧洲电力系统，覆盖12个国家的非洲南部电 力系统，覆盖14个国家的东欧/苏联电力系统. 这些巨 型电力系统纵横数千千米，通过交织密布的输电线路 为人类社会的生产和生活提供源源不断的能源动力.

\section{3 我国电力系统的发展历程}

我国最早的用电历史可以追溯到1879年的上海虹

口. 当时公共租界工部局的工程师毕晓甫利用一台 $7.46 \mathrm{~kW}$ 的柴油发电机进行发电，开启了我国用电的时 代. 但是由于经受战乱, 我国电力系统早期发展比较缓 慢. 1949年，我国电力体统的总装机容量仅为 $1.849 \times$

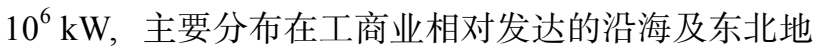
区．改革开放后，我国电力系统被定位为经济发展的 
“先行官”, 在各种利好政策的驱动下进人了高速发展 期 $^{[16]}$. 2011年, 我国的总装机容量达到 $1.057 \times 10^{9} \mathrm{~kW}$, 跃居世界第一位. 2018 年, 我国的总装机容量达到 $1.9 \times 10^{9} \mathrm{~kW}$, 是1949年的1027倍, 其中清洁能源发电的 装机容量为 $7.6 \times 10^{8} \mathrm{~kW}$, 是 1949 年的 4636 倍; $35 \mathrm{kV}$ 以上 的输电线路长达 $1.89 \times 10^{6} \mathrm{~km}$, 是 1949 年的 291 倍 ${ }^{[17]}$. 过 去10年, 我国还建成了晋东南-南阳-荆门、淮南-南京上海等多条 $1000 \mathrm{kV}$ 特高压输电线路, 是世界上正在运 行的电压等级最高的电力系统. 到目前为止, 我国电力 系统在总装机容量、清洁能源发电装机容量、电网规 模、电压等级方面均居世界第一, 人均用电量也超过 了世界平均水平 ${ }^{[18-21]}$. 此外, 我国还大量参与特高压、 新能源并网等电力系统国际标准的制定, 在特高压输 电技术、超临界发电技术、输变电设备制造等方面达

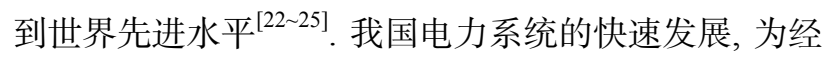
济建设提供了充足的能源, 成为我国经济崛起坚定的 推动力量.

\section{2 电力系统对现代社会的影响}

回顾电能的诞生及发展过程，特别是100多年来电 力系统的发展历程, 我们面前展现的是一幅现代社会 波澜壮阔、蓬勃发展的画面. 电力系统与各种科学技 术互为因果, 相互促进, 把人类的科学技术和生产力水 平提高到前所未有的高度. 上至国际政治经济格局, 下 至人们的生活方式, 无不因电力系统而发生巨大改变.

\section{1 电力系统对现代科学技术的影响}

电力系统是电磁、电工理论与技术不断发展的产 物, 其发展过程本身也促进了多种现代科学技术的发 展, 主要体现在以下方面:

(1) 推动材料科学与技术的发展. 电力系统由大量 发电机、变压器、输电线路、电动机等电力设备构成, 直接催生了一个巨大的电力设备市场. 电力设备对材 料的导电性、绝缘性、耐热性等有特殊要求, 促使人 们对各种固体、液体、气体材料进行广泛研究, 大量 导体、绝缘材科、超导材料、储能材料以及半导体硒 等现代半导体技术从根本上推动了材料科学与技术的 发展 ${ }^{[26-31]}$.

(2) 推动物理科学与技术的发展. 随着电源技术与 磁体技术的进步, 电子感应加速器、正负电子对撞 机、离子注人机、电磁仪器、核聚变装置等不断涌 现 $^{[32 \sim 35]}$, 从而创造了良好的物理实验实件, 并产生了现
代物理学的一个重要分支一一电物理学 ${ }^{[36]}$. 此后, 各种 物理重大发现相继出现, 物理科学与技术的发展进人 了全新的阶段.

(3) 推动化学科学与技术的发展. 电能在化学领域 的应用, 也直接产生了现代化学的一个重要分支一 电化学. 电加热可以均匀地作用到物体内部以控制化 学反应进程, 从而开辟了电解合成、电能化学等新型 化学理论体系, 界面化学、离子体化学、量子电化 学、半导体电化学、生物电化学、原电池等技术也随 着电能在化学领域的应用而得以蓬勃发展 ${ }^{[37]}$.

(4) 推动自动化科学与技术的发展. 电力系统是一 个包含发、输、配、用多个环节的耦合性极强的复杂 大系统. 为了实现电力系统的稳定、可靠运行, 需要对 电力系统的运行状态进行自动检测, 并根据当前状态 与理想状态的偏差, 按某一规则产生控制信号, 交由执 行机构对电力系统进行自动调节、控制与保护, 如此 则诞生了自动控制技术. 由于电力系统技术与自动化 技术密不可分, 电力系统的主流专业被命名为电力系 统及其自动化专业. 可以说, 从电力系统基本的遥测、 遥控和遥感功能, 到电力系统发电控制自动化、电力 调度自动化、配电自动化等生产与管理系统, 电力系 统科学与技术的发展过程本身就是一段重要的自动化 学科与技术发展史 ${ }^{[38-43]}$.

(5) 推动信息科学与技术的发展. 随着电工理论的 不断发展以及电能从“强电”往“弱电”方向延伸, 电子 管、晶体管和集成电路先后问世，信息科学与技术的 发展迎来了爆发期. 以三极管为核心的放大器、振荡 器、多谐振荡电路等器件为通信网络的形成奠定了基 础, 集成电路的出现则直接导致了电子计算机的问 $世^{[44]}$. 随着集成电路技术的不断进步, 神威“太湖之 光”、天河二号等超级计算机相继出现, 移动通信技术 也从 $1 \mathrm{G}$ 时代发展到了 $5 \mathrm{G}$ 的万物互联时代, 信息科学与 技术的发展速度惊人 ${ }^{[45 ~ 47]}$. 与此同时, 信息科学与技术 也反哺于电力系统的发展, 泛在物联网、云计算等也 作为新的信息科学形态被广泛应用于电力系统 ${ }^{[48 ~ 55]}$. 电力系统从根本上已经成为一个信息-物理系统, 信息 科学与电力系统的协同发展是未来的重要方向.

(6) 推动医学科学与技术的发展. 随着电能应用的 深人进行, 电子显微镜、心电图、X射线、超声波等电 子医学仪器相继研制成功, 从而将医学带人了精微的 世界, 病情诊断、病理分析水平大幅提高. 此外, 高频 电刀、超声刀等的投入使用，也使高难度手术成为可 
能. 可以说, 电能在医学界的广泛应用已在很大程度上 改变了传统望、闻、问、切的医学形式, 电子医学也 应运而生，医学科学与技术的发展进人了一个崭新的 时代 ${ }^{[56]}$.

\section{2 电力系统对第二次工业革命的影响}

第一次工业革命实现了机器对手工劳动的替代, 把人类社会推向 “蒸汽时代”, 生产力水平得到了巨大 提高. 以“强电”的广泛应用为标志的第二次工业革命 则进一步将人类社会由“蒸汽时代”推进到“电气时代”, 实现了人类生产力的又一次重大飞跃. 如前所述, 自 19 世纪末期发电机、电动机相继问世以及大容量远距离 输电技术出现以来, 电力系统得到了迅猛发展, 电能规 模化生产、传输与应用得以实现. 由于电能便于与机 械能、热能、光能、磁能等不同形式的能量相互转换, 且在可控性、安全性、使用效率等方面具有无可比拟 的优势, 电力逐渐取代蒸汽动力成为最重要的能源形 式. 在冶金、建筑、机械、化工、纺织等领域, 电动机 提供了比蒸汽机更大的生产力, 将19世纪的初级工业 形态发展成为现代工业体系 ${ }^{[57 ~ 59]}$. 内燃机和电车的相 继研制成功, 使交通运输走向繁荣, 这又促进了生产资 料输送以及产品分销, 工业生产由此进人了电气化大 机器时代. 企业越来越大, 生产效率越来越高, 工业总 产值超过了农业总产值，成为社会经济的主体. 此外, 围绕电力应用的各种新技术、新发明层出不穷，社会 经济、政治、生活、文化无不受到深远影响，人类社 会从“蒸汽时代”全面进人了“电气时代”.

\section{3 电力系统对第三次工业革命的影响}

电力系统对以“弱电”的广泛应用为标志的第三次 工业革命的诞生与发展具有重要推动作用. 首先, 由于 电力系统的快速发展以及电能从“强电”往“弱电”方向 延伸, 产生了通讯、信息等新型工业部门, 发展了微电 子技术、传感技术、通信技术、信号处理技术、计算 机技术、数值计算、仿真模拟等新型技术，从而引发 了第三次工业革命的萌芽. 其次, 电力系统广泛互联、 开放互动的特征，为早期信息技术的发展提供了成功 的范例. 再次, 电力系统对广域测量、高速传感、高性 能计算等计算机与信息技术的巨大需求，促进了第三 次工业革命的深化发展. 此外, 电力系统作为最大的能 源供应平台，为电子通信、电子商务等信息相关行业 提供了能源保障，推动着工业文明不断向更高的层次
和水平演进 ${ }^{[60-63]}$.

\section{4 电力系统对第四次工业革命的影响}

电力系统对以能源革命为核心的第四次工业革命 具有重要影响. 近年来, 可再生能源、人工智能、虚拟 现实、量子信息、生物基因等技术的快速发展引发了 新一轮的技术浪潮，人们普遍认识到第四次工业革命 已经来临 ${ }^{[64]}$. 但相对于前三次工业革命而言, 第四次工 业革命的技术特征更为多样，目前仍未形成一个统一 的定义. 从根本上看, 科技发展乃至工业革命的目的无 非是满足人类更高层次的需求以及摆脱环境对人类活 动的束缚. 一方面，随着社会的进步，人类在物质、精 神等方面的需求不断提高，需要通过生物基因技术获 得更健康的身体和更长的寿命，通过人工智能弥补人 类体力和脑力的局限，通过虚拟现实满足更丰富的精 神体验等 ${ }^{[65-67]}$. 另一方面, 传统的能源利用方式因能源 短缺与气候变化问题加剧而难以为继，通过能源革命 摆脱人类对传统化石能源的依赖已迫在眉睫．从这个 意义上说，能源革命将会在第四次工业革命中起到最 基本(也是最重要)的作用, 否则人类的生产与生活将会 受到越来越大的限制，其他高层次的物质与精神追求 更无从谈起. 电力系统作为能源革命的主要支撑, 是多 元化能源生产、消纳、利用的枢纽和基础平台，关系 到能源革命的成败 ${ }^{[68]}$. 从这个意义上说, 电力系统的发 展将对第四次工业革命的走向产生至关重要的影响.

\section{5 电力系统对人类生活方式的影响}

电力系统的发展为人类带来了优质、持续的电能 供应, 促使人类的生活方式出现了巨大变化. 人类对电 能的应用最早是从照明开始的，它消除了黑夜对人类 生活和生产活动的限制，改变了传统的“日出而耕，日 落而息”的生活方式．随着各种家用电器和通信设备大 量涌人人们的日常生活，人类的衣食住行已在很大程 度上建立在电气化的基础之上. 此外, 人类的医疗、教 育、娱乐等也因电能的广泛应用而发生了天翻地覆的 变化. 可以说，从物质生活到精神生活，从行为方式到 思维习惯, 从个人生活到社会群体活动, 电力系统已成 为人类生活最不可或缺的部分.

\section{6 电力系统对国际政治经济格局的影响}

电力系统作为最重要的能源基础平台和输配枢纽, 对国际政治与经济格局具有重要影响．能源与环境问 
题是当今世界的两大主题. 在能源方面, 许多国际争端 甚至战争都因能源争夺而起. 比如, 海湾战争与中东地 区的石油紧密相关, 南海等海域发现大量石油后又使 海洋争端成为新的焦点. 在环境方面, 传统的化石能源 给人类的生存环境造成了严重污染, 各国通过《京都 议定书》 《巴黎协定》等一系列条约和协定对能源总 量与二氧化碳排放量进行了限定, 但这又在很大程度 上制约了产业结构比较依赖能源消耗的发展中国家的 发展, 拉大了发达国家与发展中国家的差距.

电力系统的发展有利于从根本上解决能源与环境 问题, 重塑国际政治与经济格局. 通过电力系统, 可以 在较大的时空范围内对间歇性可再生能源进行优化消 纳, 从而实现对传统化石能源的替代, 既可以从根本上 解决能源短缺问题, 又可以减小环境的污染 ${ }^{[69 \sim 71]}$. 除此 之外, 电力系统的发展还有利于推动能源生产和消费 方式的变革, 建立新型低碳经济体系, 抵御国际能源供 应中断、能源价格急剧变化等带来的风险, 从根本上 保障国家能源安全. 近年来, 世界上的主要国家都在大 力推动电力能源清洁化的发展进程, 围绕着能源、环 境问题的国际政治与经济竞争也在一定程度上转移到 了以能源转型及能源革命为中心的角逐.

\section{7 电力系统大停电事故的影响}

由于现代社会对电力的依赖程度日益加深, 一旦 发生大停电事故, 将使现代社会瞬间陷人混乱甚至痽 疾. 比如, 2003年8月 14日北美电力系统发生停电事故, 致使美国东北部的 8 个州和加拿大东部的安大略省的 电力供应中断 29 个小时, 造成交通痽疾、通信中断、 生产与商业活动停止, 约 4000 万人的生活受到严重影 响, 经济损失接近 300 亿美元 ${ }^{[72,73]}$. 最近一次大停电事 故发生在南美电力系统. 2019年6月16日，阿根廷、乌 拉圭、巴拉圭、巴西以及智利 5 国陆续发生停电, 致使 公用设施大面积痽疾, 居民用水和通信中断, 医院与政 府无法正常运转, 将近 5000 万人经历了 “黑色周末”. 其 他大停电事故不胜枚举, 它们给社会安定、人民生活 和经济发展带来了灾难性后果 ${ }^{[74 ~ 77]}$. 如何提高电力系 统稳定性已成为电力系统运行、调度的首要任 务 ${ }^{[78 \sim 80]}$.

\section{3 面向能源革命的未来电力系统发展趋势}

自诞生以来, 电力系统已经历了一个辉煌的世纪. 当我们将目光转向未来, 电力系统在人类文明的发展
进程中将继续承担何种使命? 为了完成这些使命, 电 力系统又将如何实现自身的突破与发展? 我们必须从 更高的视角探讨未来电力系统的发展问题.

如前所述, 作为能源生产与优化配置的平台, 电力 系统的发展问题是未来能源革命战略的重要内容. 当 前盛行的能源开发与利用方式是不可持续的. 据估计, 地球上的化石能源最快可能在未来数十年内枯竭, 而 作为当前主力电源之一的水电受生态与环境约束以及 总量限制也难以提供持续、充足的电能供应 ${ }^{[81]}$. 为了 改变这种局面, 必须通过能源革命对能源系统的发展 重新定向, 逐步完成可再生能源对传统化石能源的替 代. 按照能源革命的总导向, 电力系统的基本形态、管 理机制与技术特征也将发生巨大变化. 一个清洁、互 联、开放、包容的新型电力系统正在形成，数字化与 智能化将成为电力系统的重要技术特征 ${ }^{[82]}$.

\section{1 未来电力系统的能源结构}

在能源革命的背景下, 电力系统的能源结构将出 现巨大改变. 一方面, 可再生能源的占比将不断提高. 风电、光伏发电、核电等清洁可再生能源将成为主力 电源，而传统的水电、气电、储能等灵活性资源将主 要提供辅助服务以应对可再生能源发电的随机波动性, 源-网-荷-储的灵活互动将成为电力系统的重要形

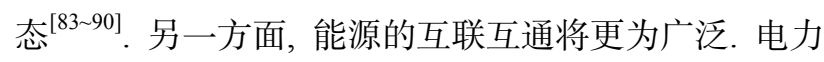
系统将与燃气系统、热力系统紧密耦合, 形成以电为 中心的能源互联网. 在能源的生产、供应和销售链条, 不同能源间的相互转化与互补互济将成为常态. 根据 效益最优原则进行多能协同规划、运行、调度与控制, 将在满足人们多元化用能需求的同时，显著提升能源 的综合利用率 ${ }^{[91 \sim 94]}$.

\section{2 未来电力系统的网络结构}

未来电力系统的网络结构将因能源结构的变化而 相应改变. 相对于传统的火力发电和水力发电而言, 风 力发电、光伏发电等可再生能源发电方式因受自然条 件的制约而更为分散，这就使“更高、更远、更大”的 传统电网发展模式面临挑战, 通过微电网就地消纳分 布式可再生能源将变得更为经济、高效与便捷 ${ }^{[95 ~ 98]}$. 此外, 为了从更大的时空范围对可再生能源发电进行 优化配置，实现不同区域间的备用共享与不确定性对 冲, 大电网仍将在能源传输中发挥重要作用. 因此, 大 电网与微电网并存, 不同层级、区域的电网的分散协 
调将成为未来电网的主要发展模式. 此外, 由于新能源 发电系统、储能系统大量接人电网以及交直流混联输 电技术的广泛应用, 电力系统的电力电子化不断增强, 系统惯性、短路容量、负荷特性、潮流特性等均会出 现显著变化, 未来电力系统的网络结构将出现由表及 里的巨大变化 ${ }^{[99 \sim 101]}$.

\section{3 未来电力系统的体制}

电力体制改革是能源革命的重要范畴，电力市场 将在未来电力系统的资源配置中起到核心作用. 从纵 向看, 电力系统的发、输、配、售等环节的一体化垄 断机制将被彻底打破，市场竞争将渗透到电力系统及 其产业链中垄断属性薄弱的环节，进而对密集的资 金、技术和人力资源进行优化配置. 从横向看，由于市 场规则、市场监管等方面的不断完善, 各种市场主体 可以在电力系统及其产业链上的每个环节进行充分博 弯, 以更公平的方式分享市场收益, 消费者也会因此而 拥有更多的选择权并享受更高品质的电能服务 ${ }^{[102,103]}$.

\section{4 未来电力系统的主要技术特征}

电力系统在能源结构、电网结构、管理体制方面 的变化, 将对其计算分析与运行决策提出巨大挑战. 传 统模型在对含复杂能源成分的电力电子化电力系统的 特性进行描述时具有较大局限性; 经典的电路理论、 电网络理论与电力系统分析方法也难以满足物理-信 息-社会融合的电力系统的分析决策需求, 基于大数据 与人工智能技术建立起新型电力系统计算与分析体系
将变得不可或缺, 数字化与智能化也将成为未来电力 系统最为重要的技术特征. 通过在各种电力设备嵌人 量测、储存与通信功能, 可以实现对电力系统的全面 感知，电力系统的规划、设计、建设、运行、管理等 各种业务也可以通过数字化的方式进行精确量度与分 析计算. 从数据的角度看, 未来电力系统将发展成为数 字电力系统 ${ }^{[104]}$, 可观性要求得到较大程度的满足. 另 一方面，通过将传统的电力技术与人工智能及大数据 技术相结合，可以克服人类在认识领域和数据处理能 力方面的极限，以更加智慧的方式提升驾驭复杂电力 系统的能力, 甚至将电力系统发展成为一个全面具备 感知、认识、决策、行动能力的巨型机器人, 实现电 力系统智能化水平的巨大飞跃 ${ }^{[105 ~ 107]}$.

\section{4 结束语}

电力系统在过去一个多世纪创造了无比灿烂辉煌 的成就. 在电力系统的强力推动下, 现代科学技术的发 展迎来了爆发期, 生产力在第二次工业革命和第三次工 业革命中实现了重大飞跃, 目前还在通过第四次工业革 命创造新的奇迹. 从基本的人类生活方式到国际政治经 济格局, 无不因电力系统而发生深刻变化. 人类社会已 经完全无法离开电力系统. 展望未来, 电力系统还将在 能源转型与能源革命中承担重要使命, 电力系统的能源 结构、网络结构、管理机制与主要技术特征均会因此 而发生显著变化. 我们应当清醒地认识电力系统的发展 规律, 实现能源与电力的可持续发展, 使电力系统这一 人类社会的能量传输大动脉奔流不息, 永葆活力.

\section{参考文献}

1 National Academy of Engineering of the United States. The Greatest Engineering Achievements of the 20th Century (in Chinese). Guangzhou: Jinan University Press, 2002 [美国国家工程院. 20世纪最伟大的工程技术成就. 广州: 暨南大学出版社, 2002]

2 Energy Research Institute National Development and Reform Commission. China 2050 High Renewable Energy Penetration Scenario and Roadmap Study (in Chinese). 2015 [国家发展和改革委员会能源研究所. 中国2050高比例可再生能源发展情景暨路径研究. 2015]

3 Research Group of Chinese Energy Development Strategy. Research on Mid-and-Long Term (2030, 2050) Energy Development Strategy of China: Comprehensive Volume (in Chinese). Beijing: Science Press, 2011. 24-27 [中国能源中长期发展战略研究项目组. 中国能源中长期 (2030、2050)发展战略研究: 综合卷. 北京: 科学出版社, 2011. 24-27]

4 National Energy Administration. National Power Industry Statistics for 2018 (in Chinese). 2019 [国家能源局. 2018年全国电力工业统计数据. 2019]

5 European Commission. European Smartgrids Technology Platform: Vision and Strategy for Europe's Electricity Networks of the Future. London: European Commission, 2006. 18-19

6 Wang Z J, Xie L L. Cyber-physical systems: A survey (in Chinese). Acta Auto Sin, 2011, 37: 1157-1166 [王中杰, 谢璐璐. 信息物理融合系统研 究综述. 自动化学报, 2011, 37: 1157-1166]

7 National Development and Reform Commission. Guidance on Promoting the Development of “Internet +" Smart Energy. 2016 [国家发展和改革 委员会. 关于推进“互联网+”智慧能源发展的指导意见. 2016] 
8 Zhou X X, Chen S Y, Lu Z X. Review and prospect for power system development and related technologies: A concept of three-generation power systems (in Chinese). Proc Chin Soc Elect Eng, 2013, 33: 1-11 [周孝信, 陈树勇, 鲁宗相. 电网和电网技术发展的回顾与展望一试论三代电网. 中国电机工程学报, 2013, 33: 1-11]

9 Wang J G, Hong Z H. Ancient Chinese Physics History (in Chinese). Shijiazhuang: Hebei People’s Publishing House, 1981 [王锦光, 洪震寰. 中 国古代物理学史话. 石家庄: 河北人民出版社, 1981]

10 Nash R T. Foudations of electricity and magnetism. Proc IEEE, 1964, 52: 224

11 Song D S, Li G D. History of Electromagnetics (in Chinese). Nanning: Guangxi People’s Publishing House, 1996 [宋德生, 李国栋. 电磁学发展 史. 南宁: 广西人民出版社, 1996]

12 Casazza J, Delea F. Understanding Electric Power Systems: An Overview of the Technology and the Marketplace. Piscataway: Wiley-IEEE Press, 2004

13 Wang Y. Review on technical development of foreign large steam turbines (in Chinese). Power Eng, 1991, 11: 1-13 [汪洋. 国外大功率汽轮机技 术发展综述. 动力工程, 1991, 11: 1-13]

14 Povh D. Use of HVDC and FACTS. Proc IEEE, 2000, 88: 235-245

15 Huang D C, Shu Y B, Ruan J J, et al. Ultra high voltage transmission in China: Developments, current status and future prospects. Proc IEEE, 2009, 97: 555-583

16 Zhou X X. Research on power system and power system in China (in Chinese). Power Sys Technol, 1989, (3): 6-11 [周孝信. 我国的电力系统和 电力系统的研究. 电网技术, 1989, (3): 6-11]

17 Bai M. 70 years of development achievements of China’s power industry. Price: Theory \& Practice, 2019, 5: 1-6 [白玫. 中国电力工业70年发展 成就. 价格理论与实践, 2019, 5: 1-6]

18 Jia J S. Overseas hydropower development and revelations to Chinese hydropower development ( I ) (in Chinese). China Water Power Electrific, 2010, (3): 6-10 [贾金生. 国外水电发展概况及对我国水电发展的启示(一). 中国水能及电气化, 2010, (3): 6-10]

19 Jia J S. Overseas hydropower development and revelations to Chinese hydropower development ( II ) (in Chinese). China Water Power Electrific, 2010, (4): 8-12 [贾金生. 国外水电发展概况及对我国水电发展的启示(二). 中国水能及电气化. 2010, (4): 8-12]

20 Tan F Z, Ju L W. Review of China's wind power development: History, current status, trends and policy (in Chinese). J North China Electr Power Univ: Soc Sci, 2013, (2): 1-7 [谭忠富, 鞠立伟. 中国风电发展综述: 历史、现状、趋势及政策. 华北电力大学学报: 社会科学版, 2013, (2): $1-7]$

21 Li X Y, Zeng Q, Wang Y H, et al. Control strategies of voltage source converter based direct current transmission system (in Chinese). High Volt Eng, 2016, 42: 3025-3037 [李兴源, 曾琦, 王渝红, 等. 柔性直流输电系统控制研究综述. 高电压技术, 2016, 42: 3025-3037]

22 Shu Y B. Research and application of 1000kV AC UHV transmission technology (in Chinese). Power Sys Technol, 2005, (19): 9-14 [舒印彪. $1000 \mathrm{kV}$ 交流特高压输电技术的研究与应用. 电网技术, 2005, (19): 9-14]

23 Wu R S. Research and application of ultra-supercritical power generation technology in China (in Chinese). Electric Power, 2006, 39: 34-37 [乌 若思. 超超临界发电技术研究与应用. 中国电力, 2006, 39: 34-37]

24 Song C, Lyu J F, Yang H R, et al. Research and application of supercritical and ultra-supercritical circulating fluidized bed boiler technology (in Chinese). Proc Chin Soc Elect Eng, 2018, 38: 338-347 [宋畅, 吕俊复, 杨海瑞, 等. 超临界及超超临界循环流化床锅炉技术研究与应用. 中国 电机工程学报, 2018, 38: 338-347]

25 Sheng G H, Liu Y D, Jiang X C, et al. Key techniques and development trends of power transmission equipment intelligentization (in Chinese) East China Electr Power, 2011, 39: 1379-1385 [盛戈暞, 刘亚东, 江秀臣, 等. 输变电设备智能化关键技术及发展趋势. 华东电力, 2011, 39: 1379-1385]

26 Zhao J K, Zhao P, Chen Z Z, et al. Review on progress of HVDC cables insulation materials (in Chinese). High Volt Eng, 2017, 43: 3490-3503 [赵健康, 赵鹏, 陈铮铮, 等. 高压直流电缆绝缘材料研究进展评述. 高电压技术, 2017, 43: 3490-3503]

27 Qiu M. Applications of superconducting power transmission in power grid (in Chinese). Adv Technol Electr Eng Energ, 2017, 36: 55-62 [丘明 超导输电技术在电网中的应用. 电工电能新技术, 2017, 36: 55-62]

28 Li Q, Yuan Y, Tan D Z. Progress on application of energy storage technology in wind power integration (in Chinese). J Hohai Univ: Nat Sci, 2010, 38: 115-122 [李强, 袁越, 谈定中. 储能技术在风电并网中的应用研究进展. 河海大学学报: 自然科学版, 2010, 38: 115-122]

29 Zhang W L, Qiu M, Lai X K. Application of energy storage technologies in power grids (in Chinese). Power Syst Technol, 2008, 32: 1-9 [张文亮, 丘明, 来小康. 储能技术在电力系统中的应用. 电网技术, 2008, 32: 1-9]

30 Amrouche S O, Rekioua D, Rekioua T. Overview of energy storage in renewable energy systems. In: 2015 3rd International Renewable and Sustainable Energy Conference (IRSEC). Marrakech: IEEE Press, 2015. 1-6

31 Miller N, Manz D, Roedel J, et al. Utility scale battery energy storage systems. In: IEEE PES General Meeting. RI: IEEE Press, 2010. 1-7

32 Deng J J. Linear Induction Electron Accelerator (in Chinese). Beijing: National Defense Industry Press, 2006 [邓建军. 直线感应电子加速器. 北 京: 国防工业出版社, 2006] 
33 Jin S, Lou X C, Ruan M Q, et al. The circular electron positron collider: Its physics, technology, and status (in Chinese). Physics, 2019, 48: 148158 [靳松, 娄辛丑, 阮曼奇, 等. 环形正负电子对撞机: 物理、技术以及现状. 物理, 2019, 48: 148-158]

34 Yang H P, Yan H D. Development of foreign ion implanters (in Chinese). Microfabr Technol, 1995, (4): 1-10 [杨洪普, 颜亨迪. 国外离子注人机 发展动态. 微细加工技术, 1995, (4): 1-10]

$35 \mathrm{Xi} \mathrm{W}$. The status quo and development trend of international nuclear fusion research and development (in Chinese). Microfabr Technol, 2006, (12): 15-16 [希物. 国际核聚变研究开发的现状和发展趋势. 中国核工业, 2006, (12): 15-16]

36 Chen J D, Liu Z Y. Dielectric Physics (in Chinese). Beijing: Mechanical Industry Press, 1982 [陈季丹, 刘子玉. 电介质物理学. 北京: 机械工业 出版社, 1982]

37 Gong Z Q. Modern Electrochemistry (in Chinese). Changsha: Central South University Press, 2010 [龚竹青. 现代电化学. 长沙: 中南大学出版 社, 2010]

38 Han F C. Power System Automation Technology (in Chinese). Beijing: China Water \& Power Press, 2003 [韩富春. 电力系统自动化技术. 北京: 中国水利水电出版社, 2003]

39 Lu Q, Sun Y Z, Mei S W. Nonlinear Control Systems and Power System Dynamics. Boston: Springer, 2001

40 Lu Q, Mei S W, Sun Y Z. Power System Nonlinear Control (in Chinese). Beijing: Tsinghua University Press, 2008 [卢强, 梅生伟, 孙元章. 电力 系统非线性控制. 北京: 清华大学出版社, 2008]

41 Lu Q, Wang Z H, Han Y D. Optimal Control of Transmission System (in Chinese). Beijing: Science Press, 1982 [卢强, 王仲鸿, 韩英铎. 输电系 统最优控制. 北京: 科学出版社, 1982]

42 Mei S W, Shen T L, Liu K Z. Modern Robust Control Theory and Application (in Chinese). Beijing: Tsinghua University Press, 2003 [梅生伟, 申 铁龙, 刘康志. 现代鲁棒控制理论与应用. 北京: 清华大学出版社, 2003]

43 Wu F F, Moslehi K, Bose A. Power system control centers: Past, present, and future. Proc IEEE, 2005, 93: 1890-1908

44 Ma J R, Wang S W. Overview of integrated circuit technology (in Chinese). Acta Electron Sin, 1985, (1): 109-116 [马俊如, 王守武. 集成电路技 术综述. 电子学报, 1985, (1): 109-116]

45 Tao J H, Liu R T, Xu K, et al. A brief history of Chinese computer development (in Chinese). Sci Technol Rev, 2016, 34: 12-21 [陶建华, 刘瑞挺, 徐恪, 等. 中国计算机发展简史. 科技导报, 2016, 34: 12-21]

46 Ministry of Industry and Information Technology of People's Republic of China. Information and Communication Industry Development Plan (2016-2020) (in Chinese). China Telecom Industry, 2017, (2): 50-63 [中华人民共和国工业和信息化部. 信息通信行业发展规划(2016-2020 年). 中国电信业, 2017, (2): 50-63]

47 Du Y, Zhu H, Yang H M, et al. Summary of 5G mobile communication technology standards (in Chinese). Telecommun Sci, 2018, 34: 2-9 [杜茎, 朱浩, 杨红梅, 等. $5 \mathrm{G}$ 移动通信技术标准综述. 电信科学, 2018, 34: 2-9]

48 Kim K D, Kumar P R. Cyber-physical systems: A perspective at the centennial. Proc IEEE, 2012, 100: 1287-1308

49 Park K J, Zheng R, Liu X. Cyber-physical systems: Milestones and research challenges. Comput Commun, 2012, 36: 1-7

50 Derler P, Lee E A, Vincentelli A S. Modeling cyber-physical systems. Proc IEEE, 2012, 100: 13-28

51 Liu D, Sheng W X, Wang Y, et al. Key technologies and trends of cyber physical system for power grid (in Chinese). Proc Chin Soc Elect Eng, 2015, 35: 3522-3531 [刘东, 盛万兴, 王云, 等. 电网信息物理系统的关键技术及其进展. 中国电机工程学报, 2015, 35: 3522-3531]

52 Zhang N, Yang J W, Wang Y, et al. 5G Communication for the ubiquitous internet of things in electricity: Technical principles and typical applications (in Chinese). Proc Chin Soc Elect Eng, 2019, 39: 4015-4025 [张宁, 杨经纬, 王毅, 等. 面向泛在电力物联网的5G通信: 技术原理 与典型应用. 中国电机工程学报, 2019, 39: 4015-4025]

53 Yang T, Zhai F, Zhao Y J, et al. Explanation and prospect of ubiquitous electric power internet of things (in Chinese). Autom Electr Power Sys, 2019, 43: 9-20 [杨挺, 翟峰, 赵英杰, 等. 泛在电力物联网释义与研究展望. 电力系统自动化, 2019, 43: 9-20]

54 Yao H Y. Big data and cloud computing (in Chinese). Inform Technol Stand, 2013, (5): 21-22 [姚宏宇. 大数据与云计算. 信息技术与标准化, 2013, (5): 21-22]

55 Rao W, Ding J Y, Lu Q K. Cloud computing platform for smart grid (in Chinese). East China Electr Power, 2011, 39: 1493-1496 [饶威, 丁坚勇, 路庆凯. 智能电网云计算平台构建. 华东电力, 2011, 39: 1493-1496]

56 Yong Y, Chang X R, Han K. Biomedical Electronics (in Chinese). Beijing: Science Press, 2014 [永远, 常向荣, 韩奎. 生物医学电子学. 北京: 科 学出版社, 2014]

57 Jevons H S. The second industrial revolution. Econ J, 1931, 41: 1-18

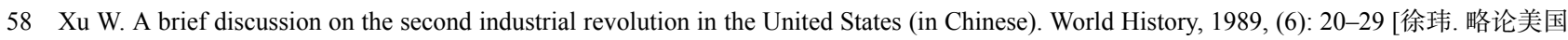
第二次工业革命. 世界历史, 1989, (6): 20-29]

59 Li F S. On the achievements and characteristics of the second industrial revolution in Germany (in Chinese). J Linyi Univ, 2012, 34: 27-31 [李富 森. 论德国第二次工业革命的成就与特点. 临沂大学学报, 2012, 34: 27-31]

60 Rifkin J. Zhang T W, Sun Y N, trans. The Third Industrial Revolution (in Chinese). Beijing: China Citic Press, 2012. 42-56 [Rifkin J, 著. 张体伟, 
孙豫宁, 译. 第三次工业革命. 北京: 中信出版社, 2012. 46-56]

61 Kaplinsky R, Cooper C E. Technology and development in the third industrial revolution. Eur J Develop Res, 1989, 1: 1-3

62 Fitzsimmons J. Information technology and the third industrial revolution. Electron Lib, 1994, 12: 295-297

63 Liu Z Y. Smart grid carries the third industrial revolution (in Chinese). State Grid, 2014, (1): 30-35 [刘振亚. 智能电网承载第三次工业革命. 国 家电网, 2014, (1): 30-35]

64 Schwab K. The Fourth Industrial Revolution. NSW: Currency Press, 2017

65 Yong W. Biobanking: Methods in Molecular Biology. New York: Humana Press, 2019. 385-402

66 Cui Y H, Shang C, Chen S Q, et al. Overview of AI: Developments of AI techniques (in Chinese). Radio Commun Technol, 2019, 45: 225-231 [崔雍浩, 商聪, 陈锶奇, 等. 人工智能综述: AI的发展. 无线电通信技术, 2019, 45: 225-231]

67 Zhao Q P. An overview of virtual reality (in Chinese). Sci Sin Inform, 2009, 39: 2-46 [赵沈平. 虚拟现实综述. 中国科学: 信息科学, 2009, 39: $2-46]$

68 Zhou X X. New generation energy system under the energy revolution (in Chinese). State Grid, 2015, (8): 58-60 [周孝信. 能源革命下的新一代 能源系统. 国家电网, 2015, (8): 58-60]

69 Chinese Academy of Engineering. Research on the Strategy of Promoting the Energy Production and Consumption Revolution (A Period) (in Chinese). 2017 [中国工程院. 推动能源生产和消费革命战略研究(一期). 2017]

70 Liu Z Y. Electric Power and Energy in China (in Chinese). Beijing: China Electric Power Press, 2012. 20-50 [刘振亚. 中国电力与能源. 北京: 中 国电力出版社, 2012. 20-50]

71 Zhou X X. Development prospects of power grid and power system technology in changes with renewable energy (in Chinese). Huadian Technol, 2011, 33: 1-3 [周孝信. 新能源变革中电网和电网技术的发展前景. 华电技术, 2011, 33: 1-3 ]

72 Yin Y H, Guo J B, Zhao J J, et al. Preliminary analysis of large scale blackout in interconnected North America power grid on August 14 and lessons to be drawn. Power Syst Technol, 2003, (10): 8-11 [印永华, 郭剑波, 赵建军, 等. 美加“8.14”大停电事故初步分析以及应吸取的教训. 电网技术, 2003, (10): 8-11]

73 Xue Y S. The way from a simple contingency to system-wide disaster-lessons from the eastern interconnection blackout in 2003. Autom Electr Power Syst, 2003, (18): 1-5 [薛禹胜. 综合防御由偶然故障演化为电力灾难一一北美“8·14”大停电的警示. 电力系统自动化, 2003, (18): 1-5]

74 Federal Energy Regulatory Commission. North American Electric Reliability Corporation. Arizona-Southern California Outages on September 8, 2011, Causes and Recommendations. 2012

75 Australian Energy Market Operator. Preliminary Report-Black System Event in South Australia on 28 September 2016. 2016

76 Fang Y J. Lessons from September 8, 2011 Southwest America blackout for prevention and control of cascading outages. Autom Electr Power Syst, 2012, 36: 1-7 [方勇杰. 美国“9·8”大停电对连锁故障防控技术的启示. 电力系统自动化, 2012, 36: 1-7]

77 Zeng H, Sun F, Li T, et al. Analysis of "9·28” blackout in South Australia and its enlightenment to China. Autom Electr Power Syst, 2017, 41: 1-6 [曾辉, 孙峰, 李铁, 等. 澳大利亚“9·28”大停电事故分析及对中国启示. 电力系统自动化, 2017, 41: 1-6]

78 Li M J, Yu Z, Xu T, et al. Study of complex oscillation caused by renewable energy integration and its solution (in Chinese). Power Syst Technol, 2017, 41: 1035-1042 [李明节, 于钊, 许涛, 等. 新能源并网系统引发的复杂振荡问题及其对策研究. 电网技术, 2017, 41: 1035-1042]

79 Zhu S, Liu K P, Qin L, et al. Analysis of transient stability of power electronics dominated power system: An overview (in Chinese). Proc Chin Soc Elect Eng, 2017, 37: 3948-3962 [朱蜀, 刘开培, 秦亮, 等. 电力电子化电力系统暂态稳定性分析综述. 中国电机工程学报, 2017, 37: 3948-3962]

80 Mei S W, Xue A C, Zhang X M. Power System Self-Organizing Criticality and Power Grid Security (in Chinese). Beijing: Tsinghua University Press, 2008 [梅生伟, 薛安成, 张雪敏. 电力系统自组织临界特性与大电网安全. 北京: 清华大学出版社, 2008]

81 Chen S S, Huang L P, Tan K X. Electrical Engineering: The Wheel of Modern Civilization (in Chinese). Jinan: Shandong People's Publishing House, 2001 [陈寿孙, 黄立培, 谈克雄. 电气工程: 现代文明之轮. 济南: 山东人民出版社, 2001]

82 Zhou X X, Lu Z X, Liu Y M, et al. Development models and key technologies of future grid in China (in Chinese). Proc Chin Soc Elect Eng, 2014, 34: 4999-5008 [周孝信, 鲁宗相, 刘应梅, 等. 中国未来电网的发展模式和关键技术. 中国电机工程学报, 2014, 34: 4999-5008]

83 Larsen H H, Sønderberg Petersen L S. Risø Energy Report 9: Non-Fossil Energy Technologies in 2050 and Beyond. Kongens Lyngby: Risø National Laboratory for Sustainable Energy, Technical University of Denmark. 2010

84 Blaabjerg F, Ma K. Wind energy systems. Proc IEEE, 2017, 105: 2116-2131

85 Yaramasu V, Wu B, Sen P C, et al. High-power wind energy conversion systems: State-of-the-art and emerging technologies. Proc IEEE, 2015, 103: $740-788$

86 Malinowski M, Leon J I, Abu-Rub H. Solar photovoltaic and thermal energy systems: Current technology and future trends. Proc IEEE, 2017, 105: $2132-2146$

87 Ursua A, Gandia L M, Sanchis P. Hydrogen production from water electrolysis: Current status and future trends. Proc IEEE, 2012, 100: 410-426

Whittingham M S. History, evolution, and future status of energy storage. Proc IEEE, 2012, 100: 1518-1534 
89 Grainger B M, Reed G F, Sparacino A R, et al. Power electronics for grid-scale energy storage. Proc IEEE, 2014, 102: 1000-1013

90 Chen G P, Li M J, Xu T, et al. Practice and challenge of renewable energy development based on interconnected power grids (in Chinese). Power Syst Technol, 2017, 41: 3095-3103 [陈国平, 李明节, 许涛, 等. 我国电网支撑可再生能源发展的实践与挑战. 电网技术, 2017, 41: 30953103]

91 Zhou X X, Zeng R, Gao F, et al. Development status and prospects of the Energy Internet (in Chinese). Sci Sin-Inf, 2017, 47: 149-170 [周孝信, 曾嵘, 高峰, 等. 能源互联网的发展现状与展望. 中国科学: 信息科学, 2017, 47: 149-170]

92 Sun H B, Guo Q L, Pan Z G. Energy internet: Concept, architecture and frontier outlook (in Chinese). Autom Electr Power Syst, 2015, 39: 1-8 [孙 宏斌, 郭庆来, 潘昭光. 能源互联网: 理念、架构与前沿展望. 电力系统自动化, 2015, 39: 1-8]

93 Huang A Q, Crow M L, Heydt G T, et al. The future renewable electric energy delivery and management (FREEDM) system: The energy Internet. Proc IEEE, 2011, 99: 133-148

94 Block C, Bomarius F, Bretschneider P, et al. Internet of Energy-ICT for Energy Markets of the Future. Berlin: Federation of German Industries. 2010

95 Li X L, Guo L, Wang C S, et al. Key technologies of DC microgrids: An overview. Proc Chin Soc Elect Eng, 2016, 36: 2-17 [李霞林, 郭力, 王成 山, 等. 直流微电网关键技术研究综述. 中国电机工程学报, 2016, 36: 2-17]

96 Justo J J, Mwasilu F, Lee J, et al. AC-microgrids versus DC-microgrids with distributed energy resources: A review. Renew Sustain Energy Rev, 2013, 24: 387-405

97 Ahmed T E, Ahmed A M, Osama A M. DC micro-grids and distribution systems: An overview. Electr Power Syst Res, 2015: 407-417

98 Nejabatkhah F, Li Y W. Overview of power management strategies of hybrid AC/DC microgrid. IEEE Trans Power Electron, 2015, 30: 70727089

99 Chen S Y, Song S F, Li L X, et al. Survey on smart grid technology. Power Syst Technol, 2009, 33: 1-7 [陈树勇, 宋书芳, 李兰欣, 等. 智能电网 技术综述. 电网技术, 2009, 33: 1-7]

100 Qian Z M, Zhang J M, Sheng K. Status and development of power semiconductor devices and its applications (in Chinese). Proc Chin Soc Elect Eng, 2014, 34: 5149-5161 [钱照明, 张军明, 盛况. 电力电子器件及其应用的现状和发展. 中国电机工程学报, 2014, 34: 5149-5161]

101 Li M J. Characteristic analysis and operational control of large-scale hybrid UHV AC/DC power grids (in Chinese). Power Syst Technol, 2016, 40: 985-991 [李明节. 大规模特高压交直流混联电网特性分析与运行控制. 电网技术, 2016, 40: 985-991]

102 Xiao Y P, Wang X F, Wang X L, et al. Review on electricity market towards high proportion of renewable energy (in Chinese). Proc Chin Soc Elect Eng, 2018, 38: 663-674 [肖云鹏, 王锡凡, 王秀丽, 等. 面向高比例可再生能源的电力市场研究综述. 中国电机工程学报, 2018, 38: 663674]

103 Mei S W, Liu F, Wei W. Fundamentals of Engineering Game Theory and Power System Application (in Chinese). Beijing: Science Press, 2016 [梅生伟, 刘锋, 魏韡. 工程博弯论基础及电力系统应用. 北京: 科学出版社, 2016]

104 Lu Q. Digital power system (DPS). Autom Electr Power Syst, 2000, 24: 1-4 [卢强. 数字电力系统(DPS). 电力系统自动化, 2000, 24: 1-4]

105 Zhou X X, Chen S Y, Lu Z X, et al. Technology features of the new generation power system in China. Proc Chin Soc Elect Eng, 2018, 38: 18931904 [周孝信, 陈树勇, 鲁宗相, 等. 能源转型中我国新一代电力系统的技术特征. 中国电机工程学报, 2018, 38: 1893-1904]

106 Peng X S, Deng D Y, Cheng S J, et al. Key technologies of electric power big data and its application prospects in smart grid. Proc Chin Soc Elect Eng, 2015, 35: 503-511 [彭小圣, 邓迪元, 程时杰, 等. 面向智能电网应用的电力大数据关键技术. 中国电机工程学报, 2015, 35: 503-511]

107 Yan L C, Bai D X, Liu W T, et al. Application and prospect of artificial intelligence technology in energy management and optimization for cloud computing data center. Proc Chin Soc Elect Eng, 2019, 39: 31-42 [间龙川, 白东霞, 刘万涛, 等. 人工智能技术在云计算数据中心能量管理中 的应用与展望. 中国电机工程学报, 2019, 39: 31-42] 


\title{
Great achievements and development trends of power systems
}

\author{
Shengwei Mei ${ }^{1,2}$ \\ ${ }^{1}$ Department of Electrical Engineering, Tsinghua University, Beijing 100084, China; \\ ${ }^{2}$ State Key Lab of Control and Simulation of Power Systems and Generation Equipments, Beijing 100084, China \\ E-mail: meishengwei@mail.tsinghua.edu.cn
}

The power system ranks the first among the greatest engineering achievements in the 20th century. With "strong electric power" as the carrier, the power system constitutes the great aorta of modern society for energy transmission; while with "weak electric power" as the carrier, the information network constitutes the nervous system of modern society. Both of them penetrate into all aspects of human society (e.g., science, production, life, international relations), and then promote the modern civilization to achieve rapid development. In terms of science, the power system has promoted the developments of materials, physics, chemistry, automation, information, medicine, and so on. This way, the system of modern science and technology is constituted. In terms of production, the second industrial revolution marked by the wide application of "strong electric power" is also called the electric power technology revolution. It has promoted another major leap in the productivity of human society after the steam revolution. The third industrial revolution marked by the widespread application of "weak electricity" is also known as the information technology revolution, which promotes the continuous evolution of industrial civilization to a much higher level. And the fourth industrial revolution, which is centered on the energy revolution, will meet the needs of human beings at a higher level and get rid of the constraints of the environment on human activities. In terms of life, electric power has become the most indispensable part of human life, ranging from material life to spiritual life, from behavioral habits to thinking ways, and from personal life to social life. In terms of international relations, the development of the power system is conducive to the fundamental solution of energy and environmental problems, thus the international political and economic competition around energy and environment has turned to the competition centered on clean power systems to some extent.

As the basic platform for energy production and supply, the development of the future power system must follow the general orientation of the energy revolution. The basic form, management mechanism and technical characteristics of the power system will also undergo tremendous changes as follows: (1) The proportion of renewable energy in the power system will be increased continuously, and the power system will be tightly coupled with gas system and thermal system to form an electricity-centric energy internet. (2) The development mode of building "higher, farther and larger" power grid will turn to the co-development mode of large power grid and small power grid, and the trend of power electronation of power system will be strengthened gradually. (3) Market competition will penetrate into the weak monopolies of the power system. Each subject can play a full game in each link, so as to obtain the optimal allocation of funds, technology and human resources. (4) Digitalization and intellectualization will be the most important technical characteristics of the future power system, which will achieve leapfrog development in observability, controllability and intellectualization.

power system, energy artery, modern civilization, great achievements, development trend

doi: $10.1360 /$ TB-2019-0641 